\title{
Implementasi Personal Selling Pembentukan Citra Produk PT. XYZ
}

\author{
Inge Hutagalung $^{1}$ dan Endriana Yuniartanti ${ }^{2}$ \\ ${ }^{1,2}$ Program Magister Ilmu Komunikasi \\ Universitas Mercu Buana Jakarta \\ Jl. Meruya Selatan No. 1 Kembangan, Jakarta Barat - Indonesia \\ Corresponding author: inge_hutagalung@mercubuana.ac.id
}

\begin{abstract}
The purpose of this study was to determine how far the implementation of marketing communication through personal selling can shape the image of a product. To answer these goals, theories and concepts related to communication, personal selling and image are used. This study uses qualitative research methods using a constructivist paradigm. Data collection techniques are carried out by observation and in-depth interviews. Based on the results of the study it can be stated that the implementation of personal selling in the formation of product images received a positive response and could increase the company's sales. Furthermore, to support sales activities it is recommended that personal selling can be combined with other marketing communication mixes such as building good relationships with customers (public relations), providing brochures and product training to customers or bringing customers to see for themselves the FAT (Factory Acceptance Test) due to the products.
\end{abstract}

Keywords: Personal Selling, Product Image, Marketing Mix

\begin{abstract}
Abstrak
Tujuan penelitian adalah untuk mengetahui sejauhmana implementasi komunikasi pemasaran melalui personal selling dapat membentuk citra suatu produk. Untuk menjawab tujuan tersebut digunakan teori dan konsep yang berhubungan dengan komunikasi, personal selling, dan citra. Penelitian ini menggunakan metode penelitian kualitatif dengan menggunakan paradigma konstruktivis. Teknik pengumpulan data dilakukan dengan observasi dan wawancara mendalam. Berdasarkan hasil penelitian dapat dikemukakan bahwa implementasi personal selling dalam pembentukan citra produk mendapat respon yang positif dan dapat meningkatkan penjualan perusahaan. Lebih lanjut, untuk menunjang kegiatan penjualan disarankan agar personal selling dapat dipadukan dengan bauran komunikasi pemasaran lain seperti membangun hubungan baik dengan pelanggan (public relations), memberikan brosur dan training produk pada pelanggan atau membawa pelanggan untuk melihat sendiri FAT(Factory Acceptance Test) untuk produk yang dijual.
\end{abstract}

Kata kunci: Personal Selling, Citra produk, Bauran Komunikasi Pemasaran

Copyright $@ 2018$ Ikatan Sarjana Komunikasi Indonesia. All rights reserved

\section{PENDAHULUAN}

Salah satu bentuk komunikasi dalam kehidupan manusia adalah pemasaran. Pemasaran dan komunikasi memiliki hubungan yang erat. Dasar dari pemasaran adalah komunikasi, dan pemasaran itu sendiri adalah sebuah konsep komunikasi. Tidak ada sebuah perusahaan yang akan berhasil menawarkan produk tanpa menetapkan strategi komunikasi yang baik kepada konsumen. Komunikasi membantu perusahaan menyampaikan pemikiran, pemahaman maupun pesan tentang suatu konsep ataupun produk untuk disampaikan kepada masyarakat ataupun konsumen (Prisgunanto, 2006:7-9).

Dalam komunikasi pemasaran, personal selling merupakan mitra penting yang tidak dapat digantikan dengan unsur promosi lainnya. Personal selling adalah improvisasi dari penjualan menggunakan komunikasi person to person (Soemanagara, 2006:33). Personal selling atau 
penjualan perorangan adalah bentuk komunikasi antar individu di mana tenaga penjual/wiraniaga menginformasikan, mendidik, dan melakukan persuasi kepada calon pembeli untuk membeli produk atau jasa perusahaan (Shimp, 2000:5). Kegiatan penjualan tatap muka (personal selling) juga merupakan proses pendidikan pasar (market education), yakni menjadikan khalayak mengetahui keberadaan serta kegunaan produk-produk dari perusahaan dimana pada akhirnya akan memperkuat citra produk maupun perusahaan (Jefkins, 2003:15).

Personal selling juga menjadi amat menarik untuk diteliti karena selain terkait pembentukan citra produk, kegiatan personal selling juga berkaitan dengan meningkatkan volume penjualan. Yaitu, jika citra produk terbentuk secara positif maka penjualan perusahaan akan meningkat. Dan sebaliknya, jika citra produk yang terbentuk negatif maka akan membuat penjualan mengalami penurunan. Bagaimana personal selling berperan terhadap pembentukan citra produk merupakan hal yang menarik untuk diteliti.

\section{KERANGKA TEORITIS}

\section{Komunikasi Pemasaran}

Komunikasi pemasaran merupakan kegiatan pemasaran dengan menggunakan teknik komunikasi seperti direct marketing, support media, personal selling, dan promosi penjualan yang bertujuan untuk memberikan informasi pada orang banyak agar tujuan perusahaan tercapai, yaitu terjadinya peningkatan penggunaan jasa atau pembelian produk yang ditawarkan yang memengaruhi tingkat penjualan. Singkat kata, komunikasi pemasaran merupakan bentuk komunikasi yang bertujuan untuk memperkuat strategi pemasaran guna meraih segmentasi yang lebih luas, memperkuat loyalitas pelanggan terhadap produk dan jasa yang dimiliki perusahaan agar tetap menggunakan produk/jasa tertentu dan tidak beralih pada produk/jasa yang sejenis (Kottler, 2012).

Pada pemasaran modern, perusahaan dituntut untuk tidak hanya sekedar mengembangkan produk, menetapkan harga yang menarik, namun juga menyediakannya informasi yang akurat bagi pelanggan sasaran. Dengan adanya informasi yang akurat, konsumen tidak akan ragu dalam melakukan pilihan dan membeli sebuah produk/jasa.

Selama ini, pemasaran dipusatkan di kegiatan periklanan dalam promosi, namun seiring dengan perkembangan waktu, pemasaran muncul sebagai bentuk komunikasi yang lebih kompleks dan berbeda melalui satu atau lebih saluran kepada kelompok khalayak sasaran yang dilakukan secara berkesinambungan dan bersifat dua arah dengan tujuan menunjang efektivitas dan efisiensi pemasaran suatu produk/jasa. Dapat disimpulkan bahwa komunikasi pemasaran merupakan serangkaian kegiatan dalam menciptakan, mengkomunikasikan, dan memberikan nilai tambah kepada pelanggan terkait produk dan jasa yang dikomunikasikan secara berkesinambungan dan bersifat dua arah dengan menggunakan komponen dari bauran promosi (promotion-mix), seperti advertising, sales promotion, public relations, direct marketing, personal selling dan komponen lainnya dalam berbagai jenis saluran media yang tersedia.

Melalui penyampaian pesan kepada konsumen diharapkan komunikasi yang dilakukan akan menghasilkan tiga tahap perubahan, yaitu perubahan knowledge (pengetahuan), perubahan sikap, dan perubahan tindakan yang dikehendaki. Tahapan pertama yang ingin dicapai dari strategi IMC adalah tahap perubahan pengetahuan (awareness change). Dalam perubahan ini, konsumen mengetahui keberadaan sebuah produk, untuk apa produk diciptakan, dan ditujukan pada siapa. Dengan demikian, pesan yang disampaikan menunjukkan informasi penting dari produk itu (Joep, 2009). 
Tahap kedua adalah tahapan perubahan sikap (attitude change), yang ditentukan oleh tiga unsur, yaitu cognition (pengetahuan), affection (perasaan), dan conation (perilaku). Jika ketiga komponen ini menunjukkan adanya kecenderungan perubahan maka akan mungkin sekali akan terjadi perubahan sikap berupa keinginan mencoba produk. Adapun tahapan ketiga adalah tahap perubahan perilaku (loyalty change), dimaksudkan agar konsumen tidak beralih pada produk lain, dan terbiasa menggunakannya atau yang biasa disebut dengan loyalitas pelanggan.

\section{Personel Selling}

Penjualan personal atau personal selling merupakan suatu bentuk komunikasi langsung antara penjual dengan calon pembeli (person-to-person communication). Dalam hal ini, penjual berupaya untuk membantu atau membujuk calon pembeli untuk membeli produk yang ditawarkan (Soemanagara, 2006).

Personal selling merupakan alat promosi yang berbeda dari periklanan. Yaitu, penjualan perseorangan dengan menggunakan orang atau individu dalam pelaksanaannya, berbeda dengan periklanan dimana pesan atau bujukan disampaikan melalui media (cetak, audio, audiovisual maupun outdoor. Komunikasi yang dilakukan orang secara individu dapat lebih fleksibel, karena terjadi interaksi personal langsung antara penjual dengan calon pembeli. Alat komunikasi umum yang digunakan pada personal selling adalah presentasi penjualan, pertemuan penjualan, program intensif serta sampel wiraniaga (Kottler, 2012).

Penjualan personal sebagai sub-elemen promosi, mempunyai dampak sangat berbeda dengan sub elemen promosi lain misal bombardir periklanan di media masa, atau dengan kegiatan promosi visual dan display lainnya yang bersifat publikasi. Personal selling lebih unggul dalam beberapa nilai, yaitu: (1) Penjualan personal memacu perusahaan untuk lebih mengenal pelanggan secara langsung, sehingga berdampak pada terkumpulnya informasi motifpembelian, (2) Personal selling dapat lebih efektif karena unsur-unsur pemasar sekaligus perusahaan menjadi sangat tahu akan reaksi pelanggan dengan begitu cepat karena unsur-unsur pemasar dapat melakukan interaksi langsung, (3) Penjualan personal dapat memacu unsur-unsur pemasar memgatahui pola dan proses pembelian yang sedang bergejolak dan trend, misal banyaknya pelanggan yang menginginkan pembelian dengan kredit, keinginan pelanggan membeli dengan proses sampel dahulu, keinginan pelanggan atau calon pelanggan yang suka dengan diskon atau bonus lainnya.

Penjualan personal sebagai salah satu strategi andalan menguntungkan perusahaan terutama dalam beberapa hal: (1) Memudahkan dalam analisa pasar secara akurat, (2) Memudahkan dalam memetakan potensi pasa, (3) Memudahkan dalam menjawab secara langsung keragaman keinginan pasar, (4) Memudahkan mendapatkan informasi reaksi pasar terhadap produk/layanan dari pesaing, (5) Mendefinsikan masalah di lapangan, sekaligus mencari solusi pengatasannya secara langsung, (6) Membangun persepsi masyarakat, dengan mengciptakan standar layanan pemasar, misal keramahan, kedekatan fisik, kepedulian sosial, performance dan penampilan, (7) Mempertahankan pelanggan secara komunikasi dua arah untuk tujuan awal meningkatkan penjualan.

\section{Citra}

Citra adalah hal yang timbul karena pemahaman akan suatu kenyataan. Citra berkaitan erat dengan persepsi, sikap (pendirian), dan opini orang perorangan dalam kelompok publik. Citra produk adalah gambaran khusus yang diperoleh konsumen mengenai produk yang masih potensial maupun yang sudah aktual. Citra produk/barang dapat terbentuk dari berbagai macam hal, misalnya: pengalaman langsung dari konsumen yang pernah memakai/mencoba produk tersebut, 
perbandingan yang dilakukan oleh konsumen yang pernah memakai produk/barang, kisah-kisah dari teman, keluarga tentang baik buruknya produk tersebut (Jefkins, 2007).

Citra terbangun karena adanya pengetahuan yang menumbuhkan pemahaman maupun pengertian. Kadangkala pemahaman dapat menjadi sesuatu yang disukai atau malah dibenci. Jika pengetahuan yang didapat menghasilkan pemahaman yang disukai maka akan timbul citra yang positif. Dan sebaliknya, jika pengetahuan yang dimiliki menghasilkan pemahaman yang tidak disukai/dibenci maka akan timbul citra yang negatif.

Menurut Jefkins (2007) ada lima hal yang dapat diadopsi oleh perusahaan dalam rangka membangun citra perusahaan dan atau citra produknya yaitu: (1) Kesatuan (single entity): produk dan perusahaan adalah satu kesatuan yang tidak terpisahkan, (2) Dominasi merek (brand dominance): tidak ada upaya untuk membuat hubungan antara produk dengan perusahaan, (3) Dominansi yang sama/adil (equal dominance): produk dan perusahaan sama sama diketahui oleh pelangan dengan bai, (4) Dominansi yang digabungkan (mixed dominance: citra perusahaan dan citra produk sama sama di munculkan secara bergantian agar keduanya menjadi suatu bauran yang saling melengkapi, (5) Dominansi Perusahaan (corporate dominance): citra perusahaan selalu dikomunikasikan agar selalu terjaga.

Adapun tahapan citra menurut Kotler (2012:568) adalah kesadaran (awareness), pengetahuan (knowledge), suka (liking), menjadikan produk sebagai pilihan (preference), yakin dengan produk (conviction), dan pembelian (purchase). Yaitu, (1) kesadaran (awareness). Kalau pasar sasaran belum mengenal produk, maka perusahaan perlu membuat promosi agar pasar sasaran mengenal produk. Dengan kata lain, pasar sasaran sadar bahwa produk itu ada. Sasaran promosi seperti ini perlu untuk produk-produk baru.

Pengetahuan (knowledge).

Bisa saja pasar sasaran kenal, sadar atau ingat nama produk, tetapi tidak tahu banyak mengenai produk. Pengetahuan merupakan respons kedua setelah kesadaran. Kalau mencapai tahap ini, tentu perusahaan harus membuat promosi yang informatif. (2) Suka (liking). Kalau target pasar sasaran sudah kenal dan tahu, bagaimana perasaan mereka terhadap produk? Kalau sudah suka atau berminat terhadap produk, berarti target pasar sasaran sudah sampai pada tahap ketiga dalam model yang kita gunakan. Bisa saja target pasar sasaran menyukai produk, tetapi tidak menempatkannya lebih penting dibanding produk-produk lain yang sama. Kalau sudah menempatkan produk sebagai pilihan pertama, maka pasar sasaran sudah sampai pada tahap preferensi dalam model.

(3) Menjadikan produk sebagai pilihan (preference). Setelah Pasar sasaran mulai menyukai produk itu Kalau sudah menempatkan produk sebagai pilihan pertama, maka pasar sasaran sudah sampai pada tahap preferensi dalam model. (4) Keyakinan (conviction). Bisa saja pasar sasaran sudah menjadikan produk sebagai pilihan, akan tetapi tidak memiliki keyakinan yang pasti mengenai produk. Kalau sudah yakin mengenai produk, biasanya orang-orang akan mempromosikan juga pada orang lain. Jadi, perusahaan dapat memperoleh promosi gratis melalui komunikasi dari mulut ke mulut (word-of-mouth communication). (5) Pembelian (purchase). Inilah tahap terakhir dalam proses. Pada akhirnya, pasar sasaran yang sudah kenal, tahu, suka, menjadikan produk sebagai pilihan dan yakin akan pilihannya, akan membeli produk pada saat yang tepat.

\section{III.METODE PENELITIAN}

Objek dalam penelitian ini adalah PT. XYZ perusahaan yang bergerak dibidang penjualan mesin kapal merk MTU (Motoren Turbine Unit) yang digunakan oleh kapal-kapal milik Angkatan 
Laut Indonesia, Bea Cukai, Departemen Kelautan Perikanan maupun Polisi Air, yang menggunakan teknik komunikasi personal selling dalam membentuk citra produk yang ditawarkannya.

Penelitian ini menggunakan paradigma konstruktivisme dengan menggunakan pendekatan kualitatif. Metode pengumpulan data primer diperoleh melalui wawancara mendalam dengan informan terpilih, dan data sekunder diperoleh melalui studi pustaka maupun analisis dokumen.

Wawancara dilakukan secara mendalam dengan menggunakan pertanyaan yang tidak berstruktur yang dimulai dengan kata tanya yang bersifat terbuka, seperti: bagaimana, apakah, dan mengapa. Wawancara mendalam akan terus dilakukan sampai peneliti mendapatkan informasi baik dari segi kualitas maupun kelengkapan informasi yang dibutuhkan. Argumentasi dipilihnya wawancara mendalam karena pertanyaan yang diajukan bersifat pribadi. Informan penelitian terdiri dari 8 orang yang terdiri dari Pimpinan PT. XYZ (3 orang) dan kastemer PT. XYZ (5 orang).

\section{HASIL PENELITIAN}

Personal selling tim marketing PT. XYZ dalam proses kerjanya berlangsung secara primer dan sekunder. Primer, yaitu proses penyampaian informasi secara langsung (face to face) dengan kastemer yang membutuhkan informasi seputar mesin. Adapun sekunder, yaitu proses penyampaian informasi melalui media seperti website, email, faximile kepada seluruh kastemer yang menjadi target sasaran penjualan mesin.

Selanjutnya proses kerja tim marketing PT. XYZ ini akan dilihat dari empat tahap atau langkah-langkah seperti yang dikemukakan oleh Kotler (2008:201) yaitu dimulai dengan tahapan memilih dan menilai prospek, tahap tahap presentasi dan demonstrasi, tahap penutupan, dan terakhir tahap tindak lanjut dan pemeliharaan konsumen.

Dalam memilih dan menilai prospek, para tenaga penjual PT. XYZ memulainya dengan melakukan survey kapal dan melihat peluang dengan mencari tahu apa yang dibutuhkan kastemer dalam pembangunan kapal baru dan lokomotifnya.

Tim marketing akan melakukan pendekatan dengan meminta data-data kapal dan data-data lokomotif yang ingin dibangun sehingga mereka dapat menentukan mesin yang ditawarkan kepada kastemer. Selain itu, akan dicari tahu pula berapa anggaran yang digunakan dalam membangun kapal termaksud. Data tersebut lalu dirapatkan dengan Sales Enginner untuk menghitung luas badan kapal, kecepatan yang diinginkan dan lebar serta panjang kapal yang berkaitan dengan perhitungan mesin untuk dimensi kapal.

Setelah menentukan mesin yang cocok digunakan untuk kapal dan lokomotif dan mengetahui kisaran budget anggaran untuk membeli mesin, maka akan dilakukan presentasi dihadapan kastemer untuk menyampaikan alasan mengapa mereka mengajukan mesin untuk dipasang pada kapal yang akan dibangun. Selanjutnya, kastemer akan melakukan perbandingan dengan melihat bagaimana kualitas mesin merek lain. Jika kastemer setuju untuk menggunakan mesin yang ditawarkan, maka akan dilakukan negosiasi harga mesin dan instalasi. Setelah negosiasi dilakukan akan diatur pelaksanaan lelang untuk mesin, dan dalam waktu kurang lebih satu bulan akan disiapkan dokumen terkait kebutuhan lelang hingga kontrak. Tahapan setelah kontrak ditanda tangani adalah pihak kastemer akan melihat Factory Acceptance Test (FAT) mesin. Proses FAT dilakukan untuk mendemonstrasikan mesin dengan tujuan untuk memberikan kepercayaan dan keyakinan lebih kepada kastemer bahwa produk yang dihasilkan berkualitas.

Proses komunikasi pemasaran personal selling yang dilakukan bukan tanpa hambatan. Hambatan yang ditemui antara lain kompetitor yang menawarkan produk yang sama, banyaknya 
keinginan konsumen yang minta untuk dipenuhi, proses pemutusan pembelian yang berbelit-belit, harga barang yang tinggi. Dari keempat hal diatas yang paling mudah ditangani dan paling banyak untuk diselesaikan adalah proses pemutusan pembelian oleh kastemer yang berbelit-belit. Dalam proses pembelian tersebut dapat memakan waktu hingga satu bulan. Dalam kurun waktu tersebut, tim marketing akan lebih meningkatkan frekuensi dalam melakukan personal selling dimana mereka lebih sering berkomunikasi dengan kastemer berkaitan dengan anggaran, after sales yang ditawarkan, kualitas mesin dibandingkan dengan mesin dari kompetitor dan service lain yang bisa ditawarkan setelah produk dibeli.

Tahap tindak lanjut dan pemeliharaan adalah tahap akhir dalam personal selling. Yaitu, setelah penandatanganan surat perjanjian maka tugas tim marketing berlanjut dengan melakukan pesanan untuk tipe mesin yang sudah dituangkan dalam surat perjanjian. Setelah pesanan mesin tiba, akan dilakukan peng-install-an mesin di kapal yang dilanjutkan dengan pengujian. Pada tahapan ini, tim marketing akan melakukan komunikasi dengan pihak kastemer untuk menyampaikan kemajuan pekerjaan pemasangan mesin sampai dengan tahap pengujian mesin. Selain melakukan pemasangan mesin, tim marketing juga melakukan evaluasi setiap minggu terkait kondisi mesin yang sdh terpasang pada kapal. Rapat evaluasi bertujuan untuk memelihara hubungan baik dengan kastemer yang sudah membeli produk mesin pada PT. XYZ.

Dalam penyusunan strategi pemasaran perlu diperhatikan tiga langkah, yaitu segmentasi pasar, penetapan target sasaran, dan positioning produk/jasa. Pasar yang heterogen, berlapis-lapis, dan tak terstruktur telah dikelompokkan dalam kotak-kotak yang lebih homogen dan terstruktur serta responsif terhadap produk/jasa, yang disebut segmentasi pasar (Soemanagara, 2006).

Terkait strategi pemasaran, peneliti melihat bahwa PT XYZ telah melakukan tiga langkah strategi pemasaran dengan diawali pemilihan dan penilaian prospek yang diikuti

presentasi produk dengan tujuan memberikan pengetahuan pada kastemer terkait kelebihan produk mesin yang diproduksi PT XYZ dibandingkan dengan produk lain. Pada saat pemilihan dan penilaian prospek, tim marketing PT XYZ fokus pada penetapan segmen pasar dan meninggalkan segmen lain yang dianggap kurang memiliki hubungan dengan produk mesin yang akan ditawarkan. Hal ini sesuai dengan kriteria pemilihan pasar sasaran sebagaimana dinyatakan oleh Kottler (2012), yaitu bahwa pasar sasaran harus responsif terhadap produk dan program pemasaran yang dikembangkan, dan berpotensi dalam penjualan, yaitu memiliki daya beli yang kuat.

Hasil penelitian juga memperlihatkan bahwa tim marketing PT ZYZ mengawali komunikasi dengan melakukan presentasi dan dilanjutkan dengan demonstrasi pada calon kastemer. Menyikapi hasil penelitian ini, peneliti mengemukakan pemikiran teoritik Littlejohn (2010) yang menjelaskan bahwa informasi merupakan hasil dari interaksi sosial dan perilaku pengolahan pesan merupakan bagian dari sistem kognitif. Yaitu, apa yang dilakukan individu dalam situasi komunikasi tidak hanya tergantung pada bentuk informasi yang diterima, tetapi juga pada operasi mental yang digunakan untuk mengolah informasi. Dengan kata lain, ada dua faktor yang memengaruhi proses pengolahan pesan pada individu yaitu kemampuan pengolahan pesan dan faktor psikologis. Bahwa manusia dalam melakukan pengolahan informasi tidak hanya dipengaruhi oleh kemampuan diri dalam pengolahan pesan namun juga dipengaruhi oleh faktor psikologis, yaitu interaksi sosial yang dilakukan sebagai perwujudan dari mahluk sosial. Terkait hasil penelitian, tampak bahwa presentasi yang disampaikan tim marketing adalah penyampaian informasi produk, sementara kunjungan pabrik merupakan sebuah proses interaksi sosial yang dilakukan untuk memengaruhi proses pengolahan pesan pada kastemer. 
Pada sisi lain, peneliti berpendapat walaupun penyampaian pesan produk PT XYZ dilakukan dengan presentasi dan demo produk namun pengolahan pesan persuasi PT XYZ tetap akan diolah oleh kastemer berdasarkan pemikiran yang kritis. Adapun argumentasi penelitia adalah karena kastemer memiliki motivasi yang kuat terhadap kebutuhan dan kepemilikan produk mesin termaksud. Singkat kata, kastemer akan mengolah pesan persuasi PT XYZ melalui jalur central.

Lebih lanjut, Petty dan Cacioppo (2005) melihat dua aspek penting yang menentukan bagaimana pesan persuasi itu diproses oleh seseorang. Salah satu aspek penting adalah motivasi seseorang dalam menerima pesan. Menurut Petty dan Cacioppo, motivasi seseorang berbeda-beda ketika menerima pesan. Perbedaan ini ditentukan oleh relevansi dari pesan persuasi itu bagi kebutuhan (baik fisik ataupun psikologis) seseorang. Makin tinggi relevansi pesan itu bagi seseorang, makin tinggi pula motivasi seseorang dalam menerima pesan, dan keinginan untuk mengetahui isi pesan. Pada saat motivasi tinggi, seseorang akan cenderung untuk menggunakan rute sentral. Ketika seseorang menggunakan rute sentral, maka yang bersangkutan akan berargumen secara hati-hati, dan juga akan mempengaruhi sikap. Keadaan sebaliknya akan terjadi, yaitu ketika seseorang mempunyai motivasi rendah maka akan digunakan rute peripheral dan tidak akan ada pengaruh banyak terhadap sikap diri.

Sementara itu, peneliti berpendapat bahwa pada tahapan penutupan dan tahapan tindak lanjut dan pemeliharaan, tim marketing PT XYZ telah memadukan antara pelaksanaan program dan strategi pamasaran dengan aktivitas program kerja public relations dalam upaya meluaskan pemasaran dan demi mencapai kepuasan konsumennya. Hal ini sesuai dengan yang dinyatakan oleh Harris (1993) bahwa diharapkan sebuah organisasi/perusahaan tidak hanya bertanggung jawab untuk penjualan produk tetapi juga bertanggung jawab untuk memperhatikan kepentingan serta kebutuhan konsumen, baik secara perorangan (melalui pemberian informasi yang jujur tentang produk) ataupun secara kelompok/masyarakat (berupa social responsibility marketing) berdasarkan visi, misi dan nilai budaya perusahaan.

Pada tahapan penutupan dan tindak lanjut dan pemeliharaan, PT XYZ telah memperhatikan dan menjalankan aspek tanggung jawab sosial. Suatu aspek yang didalam dunia public relations adalah hal yang penting. Yaitu tidak hanya memikirkan keuntungan organisasi, tetapi juga kepedulian kepada kebutuhan khalayak untuk memperoleh simpati dan dukungan. Peneliti berargumentasi bahwa PT XYZ telah mengamankan 'pangsa pasar' dengan penjelasan dan pemberian informasi mengenai produk berdasarkan fakta secara jujur (hal ini dibuktikan dengan kunjungan pabrik), dan bukan memanipulasi informasi. Dua tahapan terakhir yang dilakukan PT XYZ ini merupakan pendekatan yang dibutuhkan untuk melengkapi konsep marketing, yaitu suatu proses yang berkesinambungan dari usaha manajemen untuk memperoleh good will dan pengertian dari publik internal maupun eksternal. Kedalam, membangun budaya perusahaan, memotivasi, meningkatkan pelayanan, meningkatkan sense of belonging karyawan terhadap perusahaan. Sedangkan keluar, berupaya menciptakan kepercayaan dan citra perusahaan serta mempertahankan citra produk. Ringkasnya, public relations yang efektif akan memberikan kontribusi kepada upaya marketing dengan cara mendidik pasar, yakni menjadikan konsumen mengetahui keberadaan serta kegunaan produk dari organisasi. Baik marketing dan public relations memberikan kontribusi yang unik dan saling melengkapi untuk mengenali, mengantisipasi, dan memuaskan keinginan atau kebutuhan konsumen demi meraih laba bagi pertumbuhan dan kelangsungan hidup organisasi.

\section{KESIMPULAN}


Penjualan personal atau personal selling merupakan suatu bentuk komunikasi langsung antara penjual dengan calon pembeli (person-to-person communication). Dalam hal ini, penjual berupaya untuk membantu atau membujuk calon pembeli untuk membeli produk yang ditawarkan.

Komunikasi memegang peranan penting dalam membujuk konsumen agar berhasrat masuk ke dalam hubungan pertukaran (exchange relationship). Pada tingkat dasar, komunikasi dapat menginformasikan dan membuat konsumen menyadari atas keberadaan produk yang ditawarkan. Selanjutnya, komunikasi berperan untuk membedakan (differentiation) produk yang ditawarkan oleh satu produsen dengan produsen lainnya, upaya membedakan produk ini dilakukan dengan mengkomunikasikan kepada konsumen bahwa produk yang ditawarkan berbeda dengan produk lainnya yang sejenis. Differensasi produk juga berkaitan dengan product positioning. Dalam product positioning, produk yang ditawarkan secara fisik sebenarnya tidak jauh berbeda, tetapi pemasar membedakan produk tersebut dengan menanamkan suatu persepsi tertentu kepada konsumen, seolah-olah produk yang ditawarkan memang berbeda dari produk lainnya yang sejenis.

Di sisi lain, personal selling adalah aspek kritis dari strategi pemasaran perusahaan. Karena jika dilakukan dengan perencanaan yang matang dan berhasil akan memengaruhi volume penjualan. Namun sebaliknya, jika tidak dilakukan secara baik dan terencana maka akan membuat volume penjualan akan menurun. Jika suatu organisasi merencanakan dan mendistribusikan informasi secara sistematis maka perusahaan tengah melakukan kegiatan public relations.

Melalui pendekatan public relations, pemasaran tidak lagi diartikan dalam pengertian yang sempit yaitu hanya berupaya untuk merangsang suatu pembelian produk ataupun jasa, tetapi juga telah berkaitan dengan aspek-aspek perluasan pengaruh, informatif, persuasif dan edukatif, baik segi perluasan pemasaran (makes a marketing) untuk produk atau jasa yang dipasarkan, maupun yang terkait dengan 'perluasan' pengaruh tertentu dari kekuatan citra dan identitas lembaga/perusahaan (corporate image), yang sekaligus dapat memberikan nilai-nilai (added value) atau kepuasan bagi pihak pelanggan yang telah menggunakan produk/jasa.

\section{Daftar Pustaka}

Cornelissen, Joep. (2009). Corporate Communication: A Guide to Theory and Practice. London: Sage Publication.

Jefkins, Frank. (2007). Public Relations. Jakarta: Erlangga.

Kotler, Philip; Armstrong, Garry. (2008). Prinsip-prinsip Pemasaran, Jilid 1, Jakarta: Erlangga.

Kotler, Philip., Keller, Kevin Lane. (2012). Marketing Management. New Jersey: Pearson Education, Inc.

Littlejohn, Stephen W, Foss, Karen. (2010). Theories of Human Communication, $10^{\text {th }}$ Edition, Belmont, CA: Wadsworth.

Harris, Thomas L. (1993). The Marketer's Guide to Public Relations. New York: John Wiley and Son Inc.

Petty, Richard, John T. Cacioppo, Alan J. Stratham and Joseph Priester. (2005). To Thinks or Not to Think: Exploring Two Routes to Persuasion. Timothy C. Brock and Melanie C. Green (ed), Persuasion: Psychological Insights and Perspectives, Second Edition, Thousand Oaks: Sage Publication.

Prisgunanto, Ilham. (2006). Komunikasi Pemasaran: Strategi dan Taktik. Bogor: Ghalia Indonesia. R.D. Soemanagara. (2006). Strategic Marketing Communication, Bandung: Penerbit Alfabeta.

Shimp, Terence, A. (2003). Periklanan Promosi dan Aspek Tambahan Komunikasi Pemasaran

Terpadu, Edisi ke 5. Jakarta: Erlangga. 